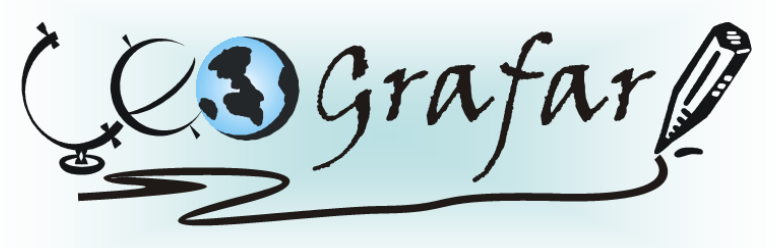

Revista Eletrônica do Programa de Pós-Graduação em Geografia - UFPR

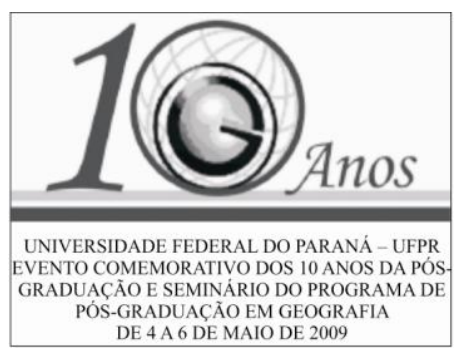

\title{
GEOGRAFIA DO COTIDIANO: REPRESENTAÇÃO ESPACIAL E RESISTÊNCIA CULTURAL NA ZONA PESSOAL COTIDIANA (ZPC) DO ESTRANGEIRO EM CASTRO
}

\section{KELTON LUIZ GABRIEL DE OLIVEIRA $^{1}$ WOLF-DRIETRICH SAHR ${ }^{2}$}

\section{LINHA DE PESQUISA: TERRITÓRIO, CULTURA E REPRESENTAÇÃO}

O trabalho se define como uma realização pragmática da metodologia denominada “Zona Pessoal Cotidiana (ZPC)”, proposta por Gabriel (2005). A ZPC é o espaço onde a pessoa vive o seu cotidiano. Seria a representação espacial dos pontos de consistência (Casa, Trabalho, Escola, etc), das trilhas psicológicas (caminhadas urbanas) e dos fragmentos espaciais promovidos pelos módulos de ligação (carros, metrô, ônibus, etc). O que há de novo no âmbito da metodologia é a inserção do que chamamos de "pontos de resistência", que seriam os lugares onde os estrangeiros interagem com uma organização espacial e social similar ao país ou cultura de origem. E essa pragmática tenta buscar padrões espaciais cotidianos no binarismo do Global e do Local em Castro, que é uma das mais propícias cidades brasileiras para observar essa manifestação da pós-modernidade, por ser antiga, conservadora e pequena evidenciando assim o tradicional local. Fazemos parte da linha de pesquisa "Território, Cultura e Representação". Em Castro iremos trabalhar com a resistência cultural de holandeses e japoneses, o que a priori são grupos de imigrantes espacialmente antagônicos, os holandeses estão resistindo em Castrolanda, enquanto os japoneses estão dispersos no espaço geográfico castrense evidenciando uma ausência perceptiva de resistência cultural.

PALAVRAS-CHAVE: Cotidiano, Geografia Cultural, Glocal.

\footnotetext{
${ }^{1}$ kelton.gabriel@gmail.com

${ }^{2}$ Professor orientador
} 